\title{
STRUCTURE CHANGES IN InP AND GaAs CRYSTALS DOUBLE IRRADIATED WITH ELECTRONS AND SWIFT HEAVY IONS
}

\author{
A. Didyk ${ }^{1}$, F. Komarov ${ }^{2}$, L. Vlasukova ${ }^{2}$, V. Yuvchenko ${ }^{2}$, Yu. Bogatyrev ${ }^{3}$, \\ F. Korshunov ${ }^{3}$, E. Gracheva ${ }^{4}$ \\ ${ }^{1}$ Laboratory of Nuclear Reactions, JINR, 141980 Dubna, Russia; \\ ${ }^{2}$ Physical Electronics Faculty, Belarusian State University, \\ 4, F. Skorina Ave, 220050, Minsk; \\ ${ }^{3}$ Solid and Semiconductor Physics Institute of National Academy of Sciences of Belarus, \\ 17, P. Brovki St., 220072 Minsk; \\ ${ }^{4}$ New Materials Chemistry Institute of National Academy of Sciences of Belarus, \\ 36, Staroborisovskii road, 220141, Minsk, Belarus
}

\begin{abstract}
We have studied InP and GaAs crystal structure changes under the influence of swift $\mathrm{Kr}$ and Bi ions irradiation by means of scanning electron microscopy, atomic force microscopy and selective chemical etching. The previous disordering of samples by electron irradiation is shown to be leading to macrodefect formation in the form of cracks and breaks at the depths near the ion end-of-range and on the crystal surface. A possible explanation of the observed effects is proposed.
\end{abstract}

\section{INTRODUCTION}

One of the ways of nanometer structuring of solids is their irradiation with swift heavy ions. Under such an irradiation the track could be created in the form of a nanometer cylinder or cluster chain with a modified structure embedded into the undamaged matrix. The mechanisms of the track formation under superhigh levels of the crystal electronic subsystem excitation are not clarified in details until now. The thermal spike model is often used to explain track formation $[1,2]$. The part of the energy used for the thermal spike formation (the heating of the possible track region) is determined by electron-phonon coupling constant $g$ characterizing the efficiency of the energy transfer from the excited electrons to the lattice atoms. The track formation in insulators and metals is observed when the electron energy losses of an ion exceed a certain threshold value $(d E / d x)_{e}$ thr determined by an irradiated material type and its structural features. For semiconductors the value of $(d E / d x)_{e t h r}$ essentially exceeds the corresponding values for insulators and could be more than 30 $\mathrm{keV} / \mathrm{nm}$. However, we have demonstrated that track formation in previously disordered InP is possible at $(d E / d x)_{e} \approx 13 \mathrm{keV} / \mathrm{nm}$ [3]. It is likely that disordering can modify electronic properties of the material thus changing a value of $g$. The modifying of electronic properties of the crystal due to the controllable embedding of the damages by light particles irradiation could be one of the ways of $(d E / d x)_{e} t h r$ reducing. The aim of the present work is to study the influence of preliminary disordering by $\mathrm{MeV}$ electron irradiation on the effects of the swift ion interaction with InP and GaAs crystals.

\section{EXPERIMENTAL}

The samples of [100]-oriented n-type GaAs and InP single crystals with $1 \times 1 \mathrm{~cm}$ sizes and thickness about of $300 \mu \mathrm{m}$ were irradiated with $4 \mathrm{MeV}$ electrons to a fluence of $2 \cdot 10^{17} \mathrm{e}^{-/ \mathrm{cm}^{2}}$. After that the virgin and previ- ously irradiated with electrons samples were bombarded with $710 \mathrm{MeV}^{209} \mathrm{Bi}$ ions to a fluence of $1.0 \cdot 10^{12} \mathrm{ion} / \mathrm{cm}^{2}$. Other series of the same GaAs and InP samples was irradiated with $23 \mathrm{MeV}$ electrons to a fluence of $3.0 \cdot 10^{17} \mathrm{e}^{-} / \mathrm{cm}^{2}$. Then a half of the area of the virgin and irradiated samples was covered by a nickel foil with the thickness exceeding ion projected range, and the samples were irradiated with $253 \mathrm{MeV}{ }^{86} \mathrm{Kr}$ ions to a fluence of $1.3 \cdot 10^{14} \mathrm{ion} / \mathrm{cm}^{2}$. The temperature of the both series of samples did not exceed $50{ }^{\circ} \mathrm{C}$ during the electron and ion irradiations.

Surface topography was investigated in the scanning electron microscope S-806 (Hitachi) and atomic force microscope "Femtoscan 001". Depth distribution of the damage was revealed by the treatment of the crystals cleaved perpendicular to the sample surface in $\mathrm{AB}$ etchant $\left(\mathrm{CrO}_{3}: \mathrm{H}_{2} \mathrm{O}: \mathrm{HF}: \mathrm{AgNO}_{3}\right)$ [4] with following observations in the optical microscope Leica INM-100. The parameters of ion and electron interactions with GaAs and InP were calculated using the TRIM-98 program [5].

\section{RESULTS AND DISCUSSION}

As our AFM data show, the electron irradiation does not change surface topography of InP and GaAs samples (not shown). The ${ }^{86} \mathrm{Kr}$ ion irradiation leads to a smoothing of the surface relief of the virgin and electron irradiated crystals. At the same time, the "ripples" appear on the irradiated part of the surface, and (in the case of InP) cones and needles arise (Fig. 1). It seems to be due to the non-uniform sputtering during the irradiation. The authors of [6-8] have studied processes of the sputtering of GaAs and $\mathrm{InP}$ crystals, and $\mathrm{Si}_{0.84} \mathrm{Ge}_{0.16}$ epitaxial layers due to the low-energy ${ }^{40} \mathrm{Ar}$ ion bombardment $\left(E_{A r}=5 \mathrm{keV}\right)$. After the irradiation "ripples" and a needle relief appear on the surface of the investigated samples similar to our samples. But, noticeable surface changes start at a fluence $\Phi_{A r} \approx 10^{15} \mathrm{ion} / \mathrm{cm}^{2}$. 
We have calculated sputtering coefficients and mean thicknesses of sputtered layers for Ar bombardment with ion energy of $5 \mathrm{keV}$ and $\Phi_{A r}=10^{15} \mathrm{ion} / \mathrm{cm}^{2}$ using elastic sputtering model. The calculated mean thicknesses of sputtered layers are $\approx 0.84 \mathrm{~nm}$ for $\mathrm{InP}$ and $1.0 \mathrm{~nm}$ for GaAs. The thicknesses of sputtered by ${ }^{86} \mathrm{Kr}$ ions InP and GaAs layers calculated for our experimen-

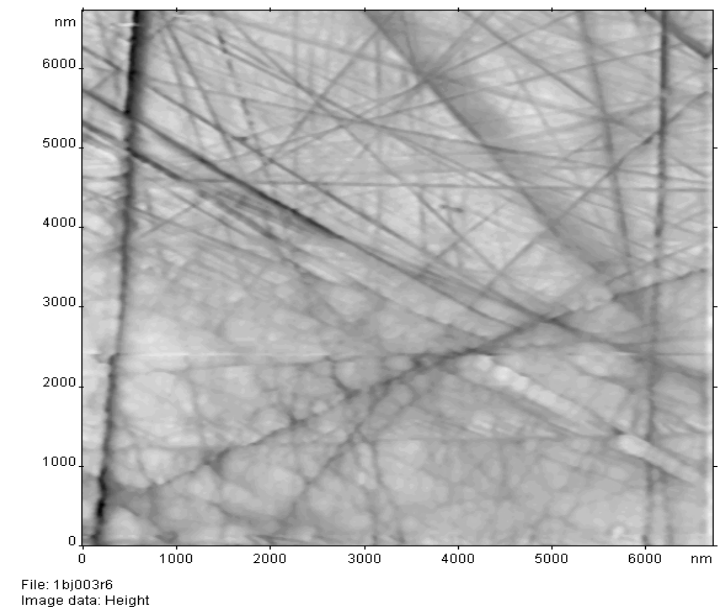

$a$ tal conditions are $9.8 \cdot 10^{-4}$ and $9.6 \cdot 10^{-4} \mathrm{~nm}$, correspondingly. These values are too small to explain the observed surface topography changes. We conclude that inelastic sputtering [9] takes place during the $253 \mathrm{MeV}$ krypton irradiation due to the high inelastic energy losses $S_{e}{ }^{K r}$ equal to $12.6 \mathrm{keV} / \mathrm{nm}$ for $\mathrm{InP}$ and $15.8 \mathrm{keV} / \mathrm{nm}$ for GaAs.
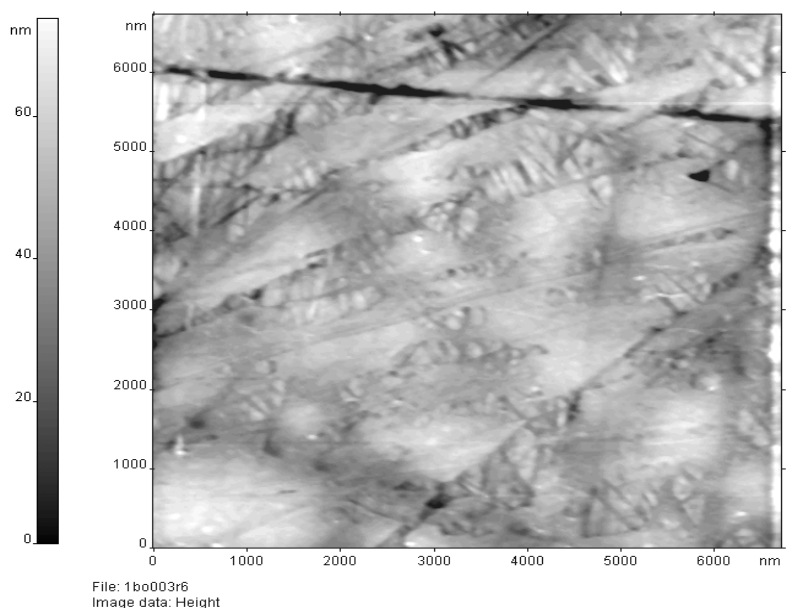

$b$

Fig. 1. Unirradiated (a) and irradiated with ${ }^{86} \mathrm{Kr}$ ions $\left(E=253 \mathrm{MeV}, \Phi_{K r}=1.3 \cdot 10^{14} \mathrm{ion} / \mathrm{cm}^{2}\right)$ and electrons $\left(E=23 \mathrm{MeV}, \Phi_{e}=3.0 \cdot 10^{17} \mathrm{e}^{-} / \mathrm{cm}^{2}\right)$ (b) InP surfaces. AFM topographic image

For GaAs crystals bombarded with electrons and ${ }^{209} \mathrm{Bi}$ ions the beginning of the flaking phenomenon has been fixed in our experiments. The region with strong mechanical damages in the form of microcracks has been revealed at cleave of the double-irradiated sample at depths exceeding the ion projected range (Fig. 2).

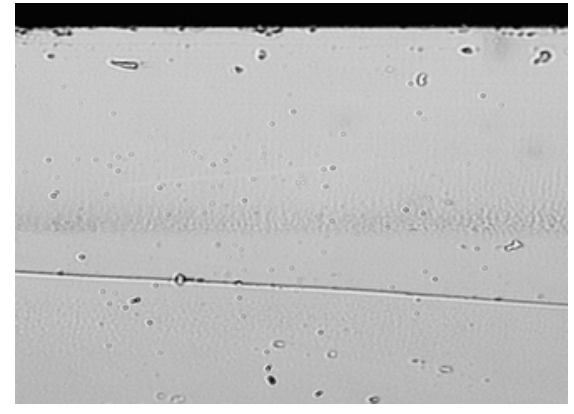

$a$

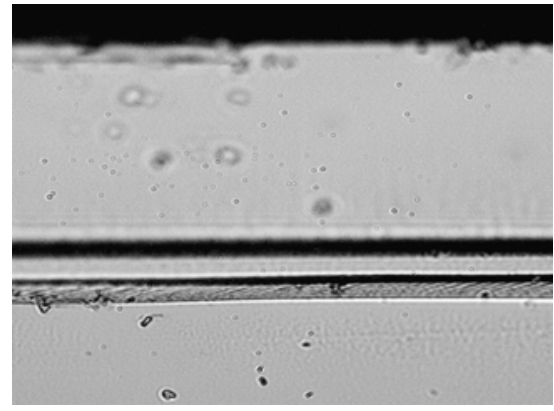

$b$

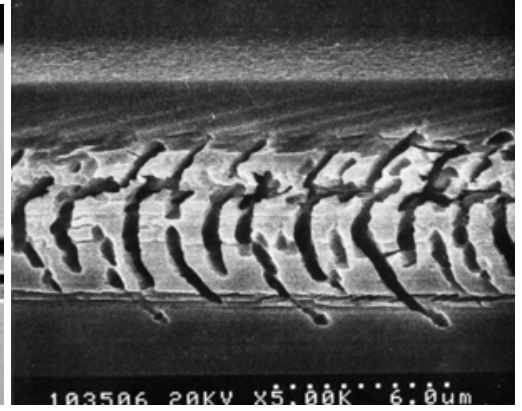

$c$

Fig. 2. Radiation damages revealed by selective chemical etching of GaAs samples cleaved perpendicular to the sample surface: $a$ - a sample irradiated with ${ }^{209} \mathrm{Bi}$ ions $\left(E=253 \mathrm{MeV}, \Phi_{B i}=1 \cdot 10^{12} \mathrm{ion} / \mathrm{cm}^{2}\right) ; b-a$ sample irradiated with electrons $\left(E=4 \mathrm{MeV}, \Phi_{e}=4.0 \cdot 10^{17} \mathrm{e}^{-} / \mathrm{cm}^{2}\right)$ and ${ }^{209} \mathrm{Bi}$ ions $\left(E=253 \mathrm{MeV}, \Phi_{B i}=1 \cdot 10^{12} \mathrm{ion} / \mathrm{cm}^{2}\right) ; \mathrm{c}-\mathrm{im}$ age with a higher magnification of the microcracks region indicated by arrow in Fig. $b$. Vertical bars in figures a and $b$ show ion projected range $R_{p}{ }^{B i}=30.6 \pm 1.0 \mu \mathrm{m}$

We have revealed also that double irradiation of InP and GaAs with electrons and ${ }^{86} \mathrm{Kr}$ ions leads to the formation of the microcracks on the surface and breaks and cleaves in the near-surface layers of double-irradiated crystal parts (Fig. 3, 4).

The authors of [1] have reported about the mechanical damage in the ionic $\left(\mathrm{LiF}\right.$ и $\left.\mathrm{CaF}_{2}\right)$ and covalent crystals $\left(\mathrm{SiO}_{2}, \mathrm{Y}_{3} \mathrm{Fe}_{5} \mathrm{O}_{12}\right.$ and $\left.\mathrm{Gd}_{3} \mathrm{Ga}_{5} \mathrm{O}_{12}\right)$ influenced by high-energy ions. Sometimes at fluences of about $10^{13}$ ion $/ \mathrm{cm}^{2}$ the irradiated layer of insulators cleaved out of the underlying undamaged crystal [1].
In our experiment the level of mechanical stresses in InP and GaAs irradiated with much higher fluence $\Phi_{\mathrm{Kr}}=1.3 \cdot 10^{14} \mathrm{ion} / \mathrm{cm}^{2}$, is found to be insufficient to destroy the material. However, the preliminary disordering of crystals by electron irradiation facilitates destruction processes during the following swift ion irradiation. The observed effects could be explained by the increasing of the volume of double-irradiated parts due to the amorphization process and by the mechanical stresses appearance in the region of swift ions stopping. The parts of the samples covered by a metal foil were not 
influenced by $\mathrm{Kr}$ ions, and in the irradiated parts the ions have been stopped in the crystal at the projected range depth. The free expansion of ion-irradiated vol-

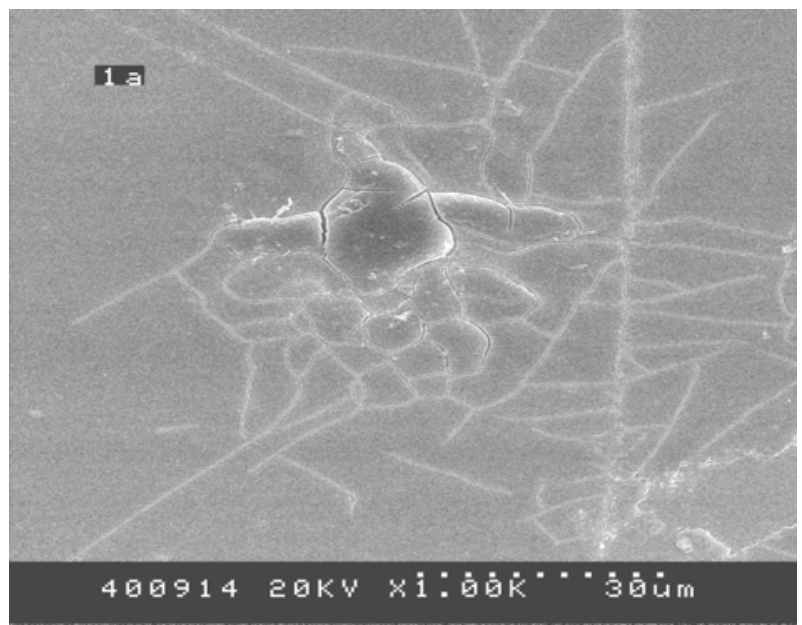

ume was limited by neighboring undamaged region. The mechanical stress appearance has led to the cracking of double irradiated material regions.

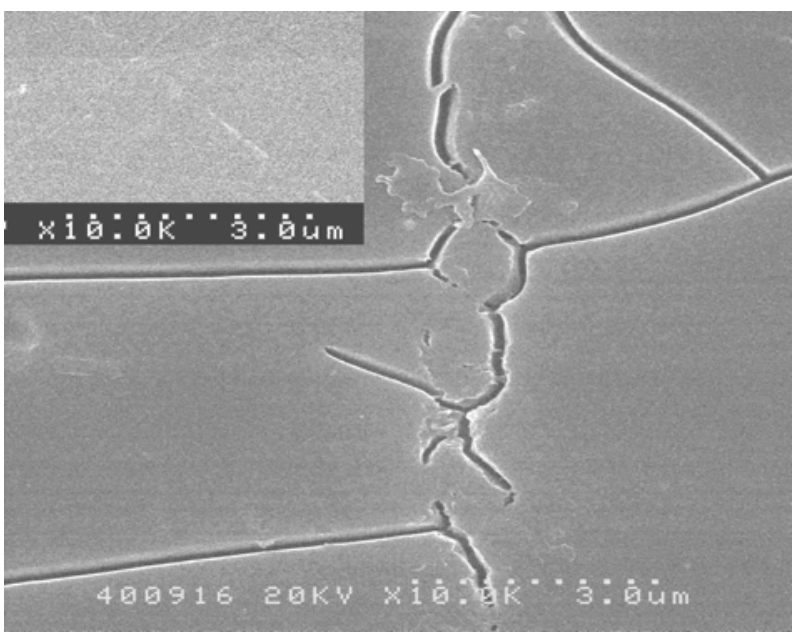

$b$

Fig. 3. Microcracks on the GaAs surface irradiated with electrons $\left(E=23 \mathrm{MeV}\right.$ and $\left.\Phi_{e}=3.0 \cdot 10^{17} e^{-} / \mathrm{cm}^{2}\right)$ and $\mathrm{Kr}$ ions $\left(E_{K r}=253 \mathrm{MeV}, \Phi_{K r}=1.3 \cdot 10^{14}\right.$ ion $\left./ \mathrm{cm}^{2}\right)$. Figures $A$ and B are scanning electron microscopy images with different magnifications. Inset on fig. B shows the sample surface irradiated with electrons only

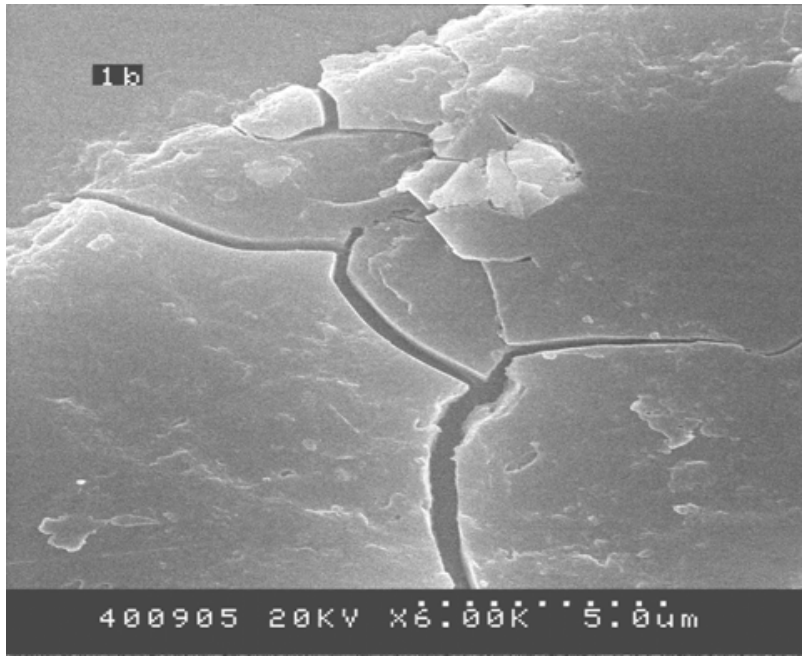

$a$

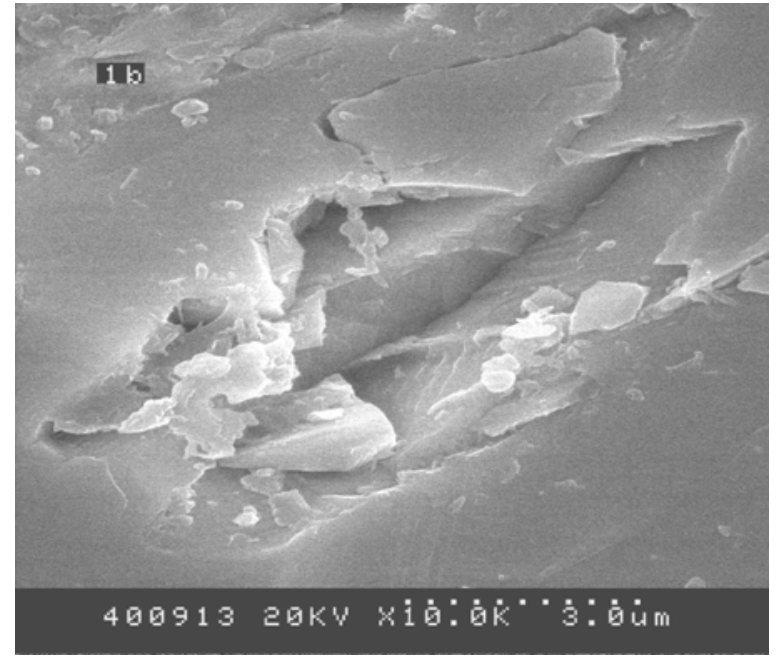

$b$

Fig. 4. Cracks and breaks on the InP surface irradiated with electrons $\left(E=23 \mathrm{MeV}, \Phi_{e}=3.0 \cdot 10^{17} \mathrm{e}^{-} / \mathrm{cm}^{2}\right)$ and $K r$ ions $\left(E_{K r}=253 \mathrm{MeV}, \Phi_{K r}=1.3 \cdot 10^{14} \mathrm{ion} / \mathrm{cm}^{2}\right)$

To explain the influence of electron irradiation facilitating mechanical destroying of the samples, we have evaluated the sensitivity of the materials under consideration to the electronic energy losses. This property is defined by the parameter $\eta=Q / \Delta H_{f}$ [2]. Here $\Delta H_{f}$ is the latent heat of fusion, $Q=0,63 \cdot S_{e} /\left(\pi \cdot \lambda^{2}\right)$ is the mean energy density deposited by the ion in a cylinder of radius $\lambda$ equal to the electron mean free path. If $\eta>\eta_{c r l}=1.3$ the lattice is considered as inelastic energy losses sensitive, if $\eta<\eta_{c r 2}=0.7$ it is insensitive to inelastic energy losses. In the range of $\eta_{c r 2} \leq \eta \leq \eta_{c r 1}$ the lack of precision of used parameters does not allow any definite conclusion. The calculated mean distances between isolated point defects generated by electron irradiation were chosen as the electron mean free path. The wave functions of free electrons in an ideal crystal represent trans- lationally invariant Bloch functions [10]. The presence of vacancies breaks crystal periodicity, and this approximation seems to be reasonable. The mean distances between point defects generated by electron irradiations are equal to 12.1 and $12.5 \mathrm{~nm}$ for $\mathrm{InP}$ and GaAs, correspondingly. These values are comparable with electron mean free paths in metals [2]. As calculations show, for InP $\eta_{K r}=0.88$. For GaAs we have $\eta_{K r}=$ $0.83, \eta_{B i}=1.34$. In all cases $\eta$ exceeds a lower limit of crystal sensitivity to electronic energy losses $\eta_{c r}=0.7$. In [11] the results describing the isotopic disorder influence on kinetic coefficients of semiconductors and alkali-halide crystals (diamond- ${ }^{12} \mathrm{C}_{1-\mathrm{x}}{ }^{13} \mathrm{C}_{\mathrm{x}},{ }^{7} \mathrm{Li}_{1-\mathrm{x}}{ }^{6} \mathrm{Li}_{\mathrm{x}} \mathrm{F}$, ${ }^{70} \mathrm{Ge}_{\mathrm{x}}{ }^{\text {nat }} \mathrm{Ge}_{1-\mathrm{x}}$ ) and models for the calculation of these coefficients changes are presented. If ${ }^{13} \mathrm{C}$ concentration in a diamond increases from $0.001 \%$ up to $10 \%$ (four 
orders of magnitude) at the room temperature $(\sim 300 \mathrm{~K})$, the thermal conductivity coefficient decreases for four times. Such significant thermal conductivity changes are caused by the change of an isotope atomic weight by one $\left({ }^{12} \mathrm{C}\right.$ replacement with $\left.{ }^{13} \mathrm{C}\right)$. In our experiment vacancies are formed in InP and GaAs crystals under the electron irradiation at damage rate $D_{E} \sim 9.3 \cdot 10^{-5} \mathrm{dpa}$. Vacancies are the centers of excited electron scattering and affect phonon propagation. This could reduce electron and lattice thermal conductivities and increase the lifetime of an overheated region around heavy ion trajectories, thus causing additional defects formation and amorphization of the irradiated layer of the crystal.

\section{CONCLUSIONS}

The influence of disordering by $\mathrm{MeV}$ electron irradiation on the swift ion interaction with $\mathrm{InP}$ and $\mathrm{GaAs}$ crystals has been studied. It has been shown that previous electron irradiations lead to macrodefect formation during the following irradiation of InP and $\mathrm{GaAs}$ with swift ions. For low ion fluences $\left({ }^{209} \mathrm{Bi}, E=710 \mathrm{MeV}\right.$; $\Phi=1.0 \cdot 10^{12} \mathrm{ion} / \mathrm{cm}^{2}$ ) the layer with macrodefects in the form of cracks is formed at the depth near the ion endof-range. With irradiation fluence increasing $\left({ }^{86} \mathrm{Kr}, E=\right.$ $253 \mathrm{MeV}, \Phi=1.3 \cdot 10^{14} \mathrm{ion} / \mathrm{cm}^{2}$ ) the macrodefects evolve, microcracks and breaks are formed on the surface of InP and GaAs crystals.

\section{REFERENCES}

1. C. Trautmann, M. Boccanfuso, A. Benyagoub et al. //Nucl. Instr. and Meth. B. 2002, v. 191, p. 144.

2. Z.G. Wang, Ch. Dufour, M. Toulemonde //J.Phys.: Condens. Matter. 1994, v. 6, p. 6733.

3.P.I. Gaiduk, F.F. Komarov, W. Wesch //Nucl. Instrum. and Meth. B. 2000, v. 164-165, p. 377.

4. M.S. Abrahams, C.J.J. Buiocchi //Appl. Phys. 1965, v. 36, p. 2855.

5. J.P. Biersack, L.G. Haggmark //Nucl. Instr. and Meth. 1980, v. B174, p. 257.

6. N.G. Van der Berg, J.B. Malherbe, R.Q. Odental et al. //Nucl. Instr. and Meth. B. 2002, v. 193, p. 739.

7. J.B. Malherbe. CRC Critical Rev. //Solid State Sci. Mater. Science. 1994, v. 19, N 55, p. 128.

8. J.B. Malherbe, R.Q. Odental //Appl. Surf. Sci. 1999, v. 144/145, p. 192.

9. I.A. Baranov, Yu.V. Martynenko, S.O. Tsepelevich, Yu. Yavlinski //N. Physics-Uspekhi. 1988, v. 156, p. 476 (in Russian).

10. Yu. Yavlinskii //Nucl. Instr. and Meth. B. 1998, v. 146, p. 142.

11. A.P. Zhernov, A.V. Inyushkin //UFN. 2002, v. 172 , p. 573 (in Russian).

\title{
СТРУКТУРНЫЕ ИЗМЕНЕНИЯ В InP и GaAs КРИСТАЛЛАХ ДВОЕКРАТНО ОБЛУЧЕННЫХ ТЯЖЕЛЫМИ ИОНАМИ И ЭЛЕКТРОНАМИ
}

\author{
А. Дидык, Ф. Комаров, Л. Власукова, В. Ювченко, Ю. Богатырев, \\ Ф. Коршунов, Е. Грачева
}

\begin{abstract}
Изучено влияние изменений структуры InP- и GaAs- при облучении ионами $\mathrm{Kr}$ и Вi и электронами при изучении методом электронной микроскопии, атомной силовой микроскопии и сективного химического травления. Основными эффектами при этом воздействии являлись образование трещин и разрушений структуры поверхности, которые наиболее значительно проявлялись в конце пробега ионов и вблизи поверхности. Возможное объяснение обнаруженных эффектов представлено.
\end{abstract}

\section{СТРУКТУРНІ ЗМІНИ В InP- і GaAs- КРИСТАЛАХ ДВОЕКРАТНО ОПРОМІНЕНИХ ВАЖКИМИ ІОНАМИ Й ЕЛЕКТРОНАМИ}

\author{
А. Дідик, Ф. Комаров, Л. Власукова, В. Ювченко, Ю. Богатирьов, \\ Ф. Коршунов, Е. Грачова
}

\footnotetext{
Вивчено вплив змін структури InP i GaAs при опроміненні іонами $\mathrm{Kr}$ і Ві й електронами при вивченні методом електронної мікроскопії, атомної силової мікроскопії й сективного хімічного травлення. Основними ефектами при цьому впливі були утворення тріщин і руйнувань структури поверхні, які найбільше значно проявлялися наприкінці пробігу іонів і поблизу поверхні. Можливе пояснення виявлених ефектів представлено.
} 